\title{
The risk of thrombo-embolic events is increased in patients with germ-cell tumours and can be predicted by serum lactate dehydrogenase and body surface area
}

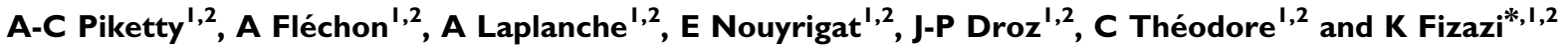 \\ 'Institut Gustave Roussy, Villejuif, France; ${ }^{2}$ Centre Léon Bérard, Lyon, France
}

The aim of this study was to evaluate the risk of thrombo-embolic events (TEE) in patients with germ-cell tumours (GCT) who receive cisplatin-based chemotherapy, to compare this risk to that of a matched control group of non-GCT cancer patients, and to identify risk factors of TEE. The rate of TEE during the 6 months following the initiation of chemotherapy was assessed in 100 consecutive patients with GCT and in 100 controls with various neoplasms who were matched on sex and age, and who received first-line cisplatin-based chemotherapy during the same period of time at Institut Gustave Roussy, Villejuif, France. Data were subsequently tested on a validation group of 77 GCT patients treated in Lyon, France. A total of 19 patients (19\%) (95\% confidence interval (Cl): 13-28) and six patients (6\%) $95 \% \mathrm{Cl}: 3-13)$ had a TEE in the GCT group and the non-GCT control group, respectively (relative risk (RR): $3.4 ; P<0.01$ ). Three patients from the GCT group died of pulmonary embolism. In multivariate analysis, two factors had independent predictive value for TEE: a high body surface area $\left(>1.9 \mathrm{~m}^{2}\right)(\mathrm{RR}: 5(1.8-13.9))$ and an elevated serum lactate dehydrogenase (LDH) (RR: $6.4(2.3-18.2))$. Patients with no risk factor $(n=26)$ and those with at least one risk factor $(n=7 \mathrm{I})$ had a probability of having a TEE of $4 \%(95 \% \mathrm{Cl}: 1-19)$ and $26 \%(95 \% \mathrm{Cl}$ : 17-37), respectively. In the GCT validation set, 10 (13\%) patients had a TEE; patients with no risk factor and those with at least one risk factor had a probability of having a TEE of 0 and 17\% (95\% Cl: 10-29), respectively. Patients with GCT are at a higher risk for TEE than patients with non-GCT cancer while on cisplatin-based chemotherapy. This risk can be accurately predicted by serum LDH and body surface area. This predictive index may help to study prospectively the impact of thromboprophylaxis in GCT patients.

British Journal of Cancer (2005) 93, 909-9|4. doi:I0.1038/sj.bjc.660279I www.bjcancer.com

Published online 4 October 2005

(c) 2005 Cancer Research UK

Keywords: cancer of the testis; chemotherapy; cisplatin; germ-cell tumour; thrombosis

The integration of cisplatin-based chemotherapy and surgery in the first-line treatment of germ-cell tumours (GCT) has resulted in cure rates of approximately $80 \%$ in disseminated cases and more than $98 \%$ when the disease is localised to the testis (Culine et al, 1996; Bosl and Motzer, 1997). The emphasis of clinical trials in the last 15 years has been to reduce the amount of early and late toxicity in patients with good-risk GCT. Late complications mainly include secondary malignancies, bleomycin-induced pulmonary fibrosis, Raynaud's phenomenon, peripheral neurotoxicity, infertility, and psychological disorders (Fizazi et al, 2002a). Moreover, some authors have suggested that there is both an increased incidence of hypercholesterolaemia (Raghavan et al, 1992) and an increased cardiovascular risk although this is still a subject of debate (Doll et al, 1986; Nichols et al, 1992; Gerl, 1994; Huddart et al, 2003).

*Correspondence: Dr K Fizazi, Department of Medicine, Institut Gustave Roussy, 39 rue Camille Desmoulins, 94800 Villejuif, France;

E-mail: fizazi@igr.fr

Received 29 March 2005; revised 25 July 2005; accepted 2 August 2005; published online 4 October 2005
Even though the matter of arterial events in GCT survivors remains controversial, there have been isolated reports on the occurrence of venous thrombo-embolic events (TEE) in these patients. However, only a few studies have specifically focused on this subject (Cantwell et al, 1988; Weijl et al, 2000). It was originally described by Trousseau that patients with cancer are at increased risk for venous TEE, although the mechanisms are not fully elucidated (Trousseau, 1865). These mechanisms may include procoagulant factors released by tumour cells, tumour-mediated vascular compression, and secondary immobilisation (Levine et al, 2002). Whether or not the use of chemotherapy increases the thrombo-embolic risk in cancer patients is still a topic of debate (Gerl, 1994). The occurrence of acute TEE in young men receiving chemotherapy for GCT has raised concerns since these complications may be life threatening and may also be responsible for longterm complications.

However, there is no definitive evidence that the TEE risk is increased in patients with GCT compared to other cancer patients. Therefore, the objectives of this study were to assess the incidence of TEE in a series of patients with GCT, to compare this incidence to that of a control population of cancer patients, and to determine predictive factors for TEE. 


\section{PATIENTS AND METHODS}

\section{Patients}

We retrospectively reviewed the incidence of TEE in a population of 100 consecutive patients with GCT, selected on the following criteria: male patients, age above 16 years, pathologic evidence of GCT (seminoma or non-seminoma), a testicular or an extragonadal primary site and first-line cisplatin-based chemotherapy given at Institut Gustave Roussy, Villejuif, France, from January 1992 to December 1998. Patients with previous chemotherapy or radiotherapy were excluded, as well as patients with a TEE diagnosed before the initiation of chemotherapy.

Thrombo-embolic event was defined as any venous or arterial thrombo-embolic complication (including superficial thrombophlebitis and thrombophlebitis on venous catheter) occurring from the first day of chemotherapy to 6 months later. This period was chosen because cisplatin has been previously associated with the occurrence of TEE and because this drug has a long-lasting activity (Schilsky et al, 1982; Gerl and Schierl, 2000). Radiologic evidence was required to ascertain the diagnosis of TEE and it was obtained by Doppler ultrasonography, CT scan, arteriography, or phlebography. The evolution of TEE was extensively studied and reported with respect to complications, relapse, and long-term functional sequel.

The incidence of TEE was also assessed in a control population and compared to that observed in patients with GCT. The control group consisted of 100 consecutive patients who were matched on the following criteria: sex, age, pathologic evidence of non-GCT neoplasm, and first-line cisplatin-based chemotherapy received at Institut Gustave Roussy during the same period of time. This control group was taken from an electronic database.

\section{Statistical methods}

Patient characteristics were obtained from the charts; they are expressed as percentages or medians (range). The predictive value of initial characteristics on the occurrence of a TEE was assessed using the log-rank test (Peto et al, 1977) for univariate analysis, and the Cox's proportional hazards regression model (Cox, 1972) for multivariate analysis. Factors with predictive value were combined to build a predictive model. All tests were two sided. The model was tested on a separate set of 70 patients with GCT treated at the Centre Léon Bérard, Lyon, France during the same period of time (validation set).

\section{RESULTS}

Characteristics from the study set of patients with GCT and the control group of patients with non-GCT malignancies are summarised in Table 1 . Both groups received cisplatin-based chemotherapy, most often at a dose of $100 \mathrm{mg} \mathrm{m}^{-2} \mathrm{cycle}^{-1}$ (Table 2). Patients from the control group had a large range of

Table I Patients characteristics

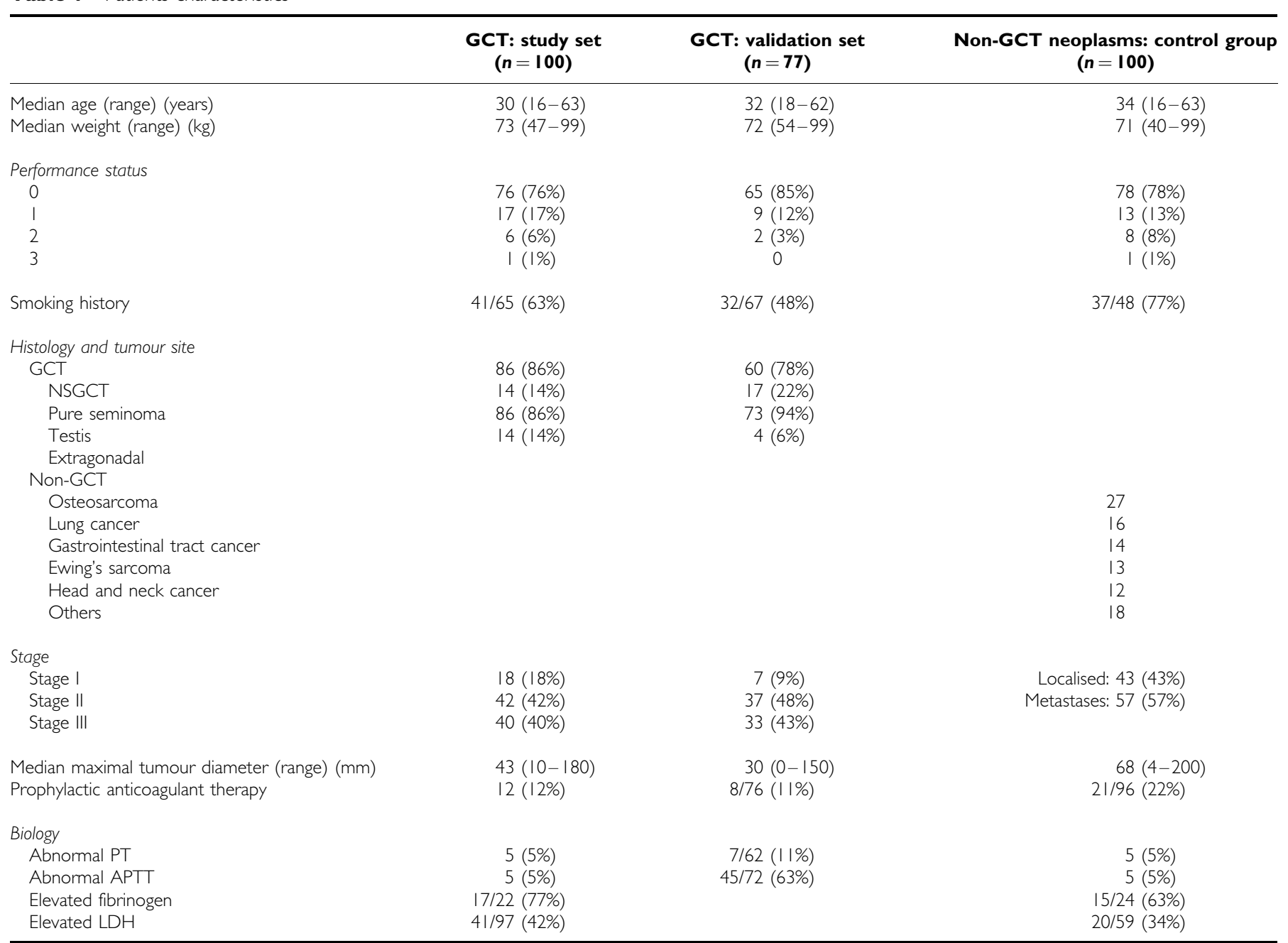

$\mathrm{GCT}=$ germ-cell tumours; NSGCT = nonseminous germ-cell tumours; $\mathrm{LDH}=$ lactate dehydrogenase; PT = prothrombine time; APTT = activated partial thromboplastin time. 
malignancies and therefore they received a variety of different chemotherapy regimens. However, all of them received cisplatinbased chemotherapy; $31 \%$ of them received the rapidly recycled cisplatin, doxorubicin, and ifosfamide (API-AI) regimen (Fizazi et al, 1997). Patients from the GCT group received cisplatin and etoposide with or without bleomycin (BEP or EP) (Culine et al, 2003), or cisplatin, doxorubicin, cyclophosphamide alternated with vinblastine and bleomycin (CISCA-VB regimen) (Fizazi et al, 2002b) (Table 2). Allocation of patients with disseminated GCT to the IGCCCG prognostic classification (IGCCCG, 1997) was as follows: good-risk group: $66 \%$; intermediate group: $4 \%$; and poorrisk group: $30 \%$. Besides tumour origin and chemotherapy, the two groups were comparable (Table 1). However, patients from the GCT group were treated less often via a central catheter than patients from the non-GCT control group ( $43 v s 74 \%, P=0.001$ ). Criteria for selecting patients for a central venous catheter included mostly a poor peripheral venous access at examination and the planned duration of chemotherapy (typically a central vein catheter was recommended in patients planned to receive more than three cycles of chemotherapy). Patients from the GCT group also had more often a disseminated disease than those from the non-GCT control group ( 82 vs $57 \%, P=0.001$ ). However, this is balanced by the fact that patients from the non-GCT control group often had tumour sites well known to be associated with thrombosis (inferior limb: 35\%; pelvis: 14\%). The duration of chemotherapy was comparable (Table 2).

\section{Thrombo-embolic events}

Overall, 19 patients (19\%) (95\% confidence interval (CI): 13-28) and six patients $(6 \%)(95 \% \mathrm{CI}: 3-13)$ had a TEE in the GCT group and the non-GCT control group, respectively (relative risk (RR): 3.4; $P<0.01$ ). Initial TEE are described in Table 3. In most cases, the first TEE occurred during the course of primary chemotherapy.

Table 2 Chemotherapy

\begin{tabular}{|c|c|c|c|}
\hline Chemotherapy & $\begin{array}{c}\text { GCT: } \\
\text { study } \\
\text { group }(n=100)\end{array}$ & $\begin{array}{c}\text { GCT: } \\
\text { validation } \\
\text { group } \\
(n=77)\end{array}$ & $\begin{array}{c}\text { Non-GCT } \\
\text { neoplasms: } \\
\text { control } \\
\text { group } \\
(n=100)\end{array}$ \\
\hline \multicolumn{4}{|l|}{ Regimen } \\
\hline BEP & $46(46 \%)$ & $46(60 \%)$ & \\
\hline EP & $42(42 \%)$ & $28(36 \%)$ & \\
\hline CISCA-VB & $12(12 \%)$ & $3(4 \%)$ & \\
\hline API-Al & & & $31(31 \%)$ \\
\hline \multicolumn{4}{|l|}{ Drugs } \\
\hline Cisplatin & $100(100 \%)$ & $77(100 \%)$ & $100(100 \%)$ \\
\hline Etoposide & $88(88 \%)$ & $74(96 \%)$ & || (| |\%) \\
\hline Bleomycin & $58(58 \%)$ & $49(63 \%)$ & $4(4 \%)$ \\
\hline Doxorubicin & $12(12 \%)$ & $3(4 \%)$ & $31(31 \%)$ \\
\hline Cyclophosphamide & $12(12 \%)$ & $3(4 \%)$ & I (I\%) \\
\hline Vinblastine & $12(12 \%)$ & $3(4 \%)$ & $5(5 \%)$ \\
\hline Ifosfamide & & & $36(36 \%)$ \\
\hline Epirubicine & & & II (I I\%) \\
\hline Vinorelbine & & & $8(8 \%)$ \\
\hline 5-Fluorouracil & & & $7(7 \%)$ \\
\hline$\alpha$-Interferon & & & $2(2 \%)$ \\
\hline Thiotepa & & & I (I\%) \\
\hline Docetaxel & & & I (I\%) \\
\hline Interleukin-2 & & & I (I\%) \\
\hline Mitomycin C & & & I (I\%) \\
\hline Duration of chemotherapy (days) & $63(6-408)$ & $68(4-129)$ & $51(3-258)$ \\
\hline Neutropenic fever & $19(19 \%)$ & $24(33 \%)$ & $16(16 \%)$ \\
\hline Postchemotherapy surgery & $39(39 \%)$ & 40 (52\%) & $39(39 \%)$ \\
\hline
\end{tabular}

$\mathrm{CGT}=$ germ-cell tumours.
A second TEE occurred in eight and three patients in the GCT group and the non-GCT group, respectively (Table 4). Both patients who initially had a superficial venous thrombosis of the arm subsequently developed a deep venous thrombosis: thrombosis of the leg and pulmonary embolism in the first patient and lethal pulmonary embolism in the second patient. These two patients were only receiving a topical anti-inflammatory treatment for their superficial thrombosis when the deep venous thrombosis occurred. The other six patients were all receiving anticoagulant therapy when the second TEE occurred. Overall, two patients from the GCT group had an arterial TEE and both also had a venous

Table 3 First TEE

\begin{tabular}{|c|c|c|c|}
\hline & $\begin{array}{l}\text { GCT: } \\
\text { study } \\
\text { group } \\
(n=100)\end{array}$ & $\begin{array}{c}\text { GCT: } \\
\text { validation } \\
\text { group } \\
(n=77)\end{array}$ & $\begin{array}{c}\text { Non-GCT } \\
\text { neoplasms: } \\
\text { control group } \\
(n=100)\end{array}$ \\
\hline Patients with a first TEE & 19 & 10 & 6 \\
\hline \multicolumn{4}{|l|}{ Timing of the first TEE } \\
\hline During chemotherapy & 14 & 7 & 4 \\
\hline After the end of chemotherapy & 5 & 3 & 2 \\
\hline Deep venous thrombosis & 16 & 9 & 6 \\
\hline Leg & 6 & 3 & \\
\hline Arm & 4 & I & \\
\hline Inferior vena cava & 4 & I & 5 \\
\hline Superior vena cava & & I & 1 \\
\hline Pulmonary embolism & 1 & 2 & \\
\hline Renal vein & 1 & । & \\
\hline Superficial venous thrombosis & $2^{a}$ & $1^{a}$ & 0 \\
\hline Arterial thrombosis & । & 0 & 0 \\
\hline Stroke & I & & \\
\hline
\end{tabular}

all these patients subsequently developed a deep venous thrombosis. GCT = germcell tumours; TEE = thrombo-embolic events; PT = prothrombine time; .APTT = activated partial thromboplastin time.

Table 4 Complications of TEE

\begin{tabular}{|c|c|c|c|}
\hline & $\begin{array}{c}\text { GCT: } \\
\text { study group } \\
\text { ( } n=19 \\
\text { first TEE) }\end{array}$ & $\begin{array}{c}\text { GCT: } \\
\text { validation } \\
\text { group } \\
\text { ( } n=10 \\
\text { first TEE) }\end{array}$ & $\begin{array}{c}\text { Non-GCT } \\
\text { neoplasms: } \\
\text { control group } \\
(n=6 \text { first TEE) }\end{array}$ \\
\hline Relapse of TEE & $8^{a}$ & $1^{a}$ & $3^{a}$ \\
\hline \multicolumn{4}{|l|}{ Venous } \\
\hline Pulmonary embolism & 7 & & 2 \\
\hline Leg & । & I & I \\
\hline Arm & 2 & & \\
\hline Inferior vena cava & & I & \\
\hline \multicolumn{4}{|l|}{ Arterial } \\
\hline Acute ischaemia of the leg & I & & \\
\hline Long-term sequels & $6^{b}$ & $3^{b}$ & $3^{b}$ \\
\hline Oedema of the leg & 4 & 2 & 2 \\
\hline $\begin{array}{l}\text { Peripheral venous } \\
\text { circulation or dermitis }\end{array}$ & 2 & I & \\
\hline Chronic pain & 2 & & \\
\hline Walking limitation & I & & \\
\hline Renal failure & & & 1 \\
\hline Death & 3 & 0 & 0 \\
\hline
\end{tabular}

a Some patients had multiple sites of second TEE. ${ }^{b}$ Some patients had multiple sequels. TEE $=$ thrombo-embolic events; GCT = germ-cell tumours. 
TEE: in the first patient, a lethal pulmonary embolism occurred 6 weeks after a stroke, and in the second patient, a venous thrombosis of the superior cava vena related to a central catheter was followed 10 days later by an acute ischaemia of the leg (no long-term sequel after arterial thrombectomy).

Long-term complications occurred in six and three patients in the two groups, respectively. Three patients from the GCT group died of pulmonary embolism (one of them having also a stroke).

\section{Univariate analysis}

A number of parameters were tested in univariate analysis to assess whether they were predictors of a first TEE in the GCT group (Table 5). Six parameters had a significant predictive value for TEE: age $>30$ years, a histology of pure seminoma, weight $>70 \mathrm{~kg}$, body surface area $>1.9 \mathrm{~m}^{2}$, elevated serum lactate dehydrogenase (LDH), and elevated serum alkaline phosphatase.

\section{Multivariate analysis}

Predictive factors of TEE identified in univariate analysis were tested in multivariate analysis using the Cox model. Two models were built by entering either weight or body surface area in the analysis. Results are summarised in Table 6 . In the first model, two factors had independent predictive value for TEE: a high body surface area $\left(>1.9 \mathrm{~m}^{2}\right)$ and an elevated serum LDH. In the second model, weight over $70 \mathrm{~kg}$ and an elevated serum LDH were independent predictors of TEE.

The first model was used to build a risk index for TEE: patients with no risk factor (body surface area $\leqslant 1.9 \mathrm{~m}^{2}$ and normal serum LDH; $n=26)$ and those with at least one risk factor $(n=71)$ had a probability of having a TEE of $4 \%(95 \%$ CI: $1-19)$ and $26 \%(95 \%$ CI: 17-37), respectively.

\section{Validation set}

To validate these data, a separate set of 70 patients with GCT treated at the Centre Léon Bérard, Lyon, France, during the same period of time was analysed. Their characteristics are summarised in Tables 1 and 2. Patient characteristics were similar in the study set and the validation set. Overall, $10(13 \%)$ of patients from the validation set had a TEE in the first 6 months following the start of chemotherapy (Tables 3 and 4 ). The only patient with a superficial venous thrombosis subsequently developed a deep venous thrombosis (leg and inferior vena cava).

Independent predictive factors of TEE identified in the study set were tested in this validation population: elevated serum LDH and a high body surface area were associated with a relative risk of TEE of 4.6 (95\% CI: 0.6-37.9) and 1.7 (95\% CI: 0.4-7.1) respectively. When the risk index of TEE was tested in this population, patients with no risk factor (body surface area $\leqslant 1.9 \mathrm{~m}^{2}$ and a normal serum LDH; $n=16)$ and those with at least one risk factor $(n=60)$ had a probability of having a TEE of 0 and $17 \%$ (95\% CI: $10-29)$, respectively.

\section{DISCUSSION}

In this study, we provide evidence for the first time that patients with GCT who receive cisplatin-based chemotherapy are at a significantly higher risk of having a thrombosis in the subsequent 6 months compared with those with other cancers who received similar treatments. Moreover, the risk of having a thrombosis could be predicted in GCT patients using two simple factors: a high body surface area $\left(>1.9 \mathrm{~m}^{2}\right.$ ) (or a high weight) and an elevated serum LDH before chemotherapy. Patients with no risk factor had a risk of thrombosis of $4 \%$ while those with at least one risk factor had a risk of $26 \%$. These features were 0 and $17 \%$ respectively in a
Table 5 Univariate analysis of predictive factors for TEE in patients with GCT

\begin{tabular}{|c|c|c|c|}
\hline Characteristics & Number of TEE & $P$ & Relative risk \\
\hline \multicolumn{4}{|l|}{ Age (years) } \\
\hline$\leqslant 30$ & 3 & 0.001 & 1 \\
\hline$>30$ & 16 & & 6.8 \\
\hline \multicolumn{4}{|l|}{ Weight $(\mathrm{kg})$} \\
\hline$\leqslant 70$ & 3 & 0.002 & 1 \\
\hline$>70$ & 16 & & 5.5 \\
\hline \multicolumn{4}{|l|}{ Body surface area $\left(\mathrm{m}^{2}\right)$} \\
\hline$\leqslant 1.9$ & 5 & 0.01 & 1 \\
\hline$>1.9$ & 14 & & 3.4 \\
\hline \multicolumn{4}{|l|}{ Performance status (WHO) } \\
\hline $0-1$ & 17 & 0.31 & \\
\hline $2-3$ & 2 & & \\
\hline \multicolumn{4}{|l|}{ Histology } \\
\hline Pure seminoma & 6 & 0.01 & 3.4 \\
\hline NSGCT & 13 & & । \\
\hline \multicolumn{4}{|l|}{ Primary tumour site } \\
\hline Testis & 16 & 0.7 & \\
\hline Extragonadal & 3 & & \\
\hline \multicolumn{4}{|l|}{ IGCCCG classification } \\
\hline Good & 10 & 0.36 & \\
\hline Intermediate or poor & 7 & & \\
\hline \multicolumn{4}{|l|}{ Stage before chemotherapy } \\
\hline Stage I & 2 & 0.63 & \\
\hline Stage II & 9 & & \\
\hline Stage III & 8 & & \\
\hline \multicolumn{4}{|c|}{ Maximal tumour diameter ( $\mathrm{mm}$ ) } \\
\hline$\leqslant 40$ & 4 & 0.15 & \\
\hline$>40$ & 8 & & \\
\hline \multicolumn{4}{|l|}{ Central venous catheter } \\
\hline Yes & 11 & 0.14 & \\
\hline No & 8 & & \\
\hline \multicolumn{4}{|l|}{ Febrile neutropenia } \\
\hline Yes & 6 & 0.09 & 2.2 \\
\hline No & 13 & & 1 \\
\hline \multicolumn{4}{|c|}{ Preventive anticoagulant therapy } \\
\hline Yes & 4 & 0.15 & \\
\hline No & 15 & & \\
\hline \multicolumn{4}{|l|}{ Alkaline phosphatase } \\
\hline Normal & 16 & 0.00001 & 1 \\
\hline Elevated & 3 & & 14.5 \\
\hline \multicolumn{4}{|l|}{ PT, APTT } \\
\hline Norma & 13 & 0.08 & 1 \\
\hline Abnormal & 6 & & 2.3 \\
\hline \multicolumn{4}{|l|}{$\mathrm{LDH}$} \\
\hline Normal & 5 & 0.01 & 1 \\
\hline Elevated & 14 & & 4.6 \\
\hline
\end{tabular}

NSGCT = nonseminous germ-cell tumours; $\quad$ TEE $=$ thrombo-embolic events; $\mathrm{LDH}=$ lactate dehydrogenase; $\mathrm{PT}=$ prothrombine time; $\mathrm{APTT}=$ activated partial thromboplastin time.

validation set of patients with GCT treated in a different institution. Morbidity and mortality were relevant in this population of young men who are likely to achieve a cure of their 
Table 6 Multivariate analysis

\begin{tabular}{lcc}
\hline & Relative risk (95\% Cl) & $P$ \\
\hline Model I & $5.0(1.8-13.9)$ & \\
$\quad$ Body surface area $>1.9 \mathrm{~m}^{2}$ & $6.4(2.3-18.2)$ & 0.01 \\
Elevated LDH & & \\
& & \\
Model 2 & $7.4(2.1-25.6)$ & 0.01 \\
Weight $>70 \mathrm{~kg}$ & $5.9(2.1-16.6)$ & 0.01 \\
Elevated LDH & & \\
\hline
\end{tabular}

$\mathrm{LDH}=$ lactate dehydrogenase.

cancer. TEE consisted mainly in venous thrombosis, with arterial events being more rare.

A large number of TEE occurring in GCT patients have been published as case reports (Doehn et al, 2000; Koga et al, 2001; Blokh et al, 2003; Leslie et al, 2003; cases published before 2000 reviewed in Weijl et al, 2000). In a British series of 333 patients with advanced GCT, the incidence of vena cava compression was $9.3 \%$, of whom $29 \%$ had a thrombo-embolic complication and one patient died of pulmonary embolism (Hassan et al, 1999). Two previous studies also underscored the apparent high risk of TEE in GCT patients receiving chemotherapy, although there was no control group in these studies (Cantwell et al, 1988; Weijl et al, 2000). In a series of 52 patients, Cantwell et al (1988) reported 10 TEE (19\%), including seven venous events, three arterial events, and one death. In another series of 179 patients, Weijl et al (2000) reported 15 TEE (8\%), including 13 venous events, two arterial events, and one death. Moreover, a recent study with a 10 -year follow-up showed that GCT survivors are at a higher cardiac risk than controls in the long term (Huddart et al, 2003). Therefore, based on our experience and previous publication, there is evidence that GCT patients have a three-fold higher risk of TEE (consisting mostly in venous events) during chemotherapy and soon afterwards, and that they have a two-fold higher risk of cardiac events in the long term.

The pathogenesis of TEE in GCT patients is not fully understood. Whether the causes are cancer related, treatment related, or both is still unknown. One weakness of our study was the relatively high number of parameters that were tested in univariate analysis compared to the limited number of patients (100). In the Weijl series, liver metastases and high doses of steroids (used as antiemetics) were independent predictors of TEE, but these factors were not tested in a separate set of GCT patients (Weijl et al, 2000). In our study, the fact that CGT patients had a much higher risk for TEE than non-GCT cancer patients, even though both received cisplatin-based chemotherapy, indicates that cisplatin itself is not the only risk factor for TEE, in contrast with previous hypothesis
(Icli et al, 1993). However, we can certainly not rule out a direct or indirect role of chemotherapy in the pathogenesis of TEE. Other drugs, in particular bleomycin (Schwarzer et al, 1991) and etoposide (Schwarzer et al, 1991; Airey et al, 1995), as well as the traditional 5-day protocols used in GCT might favour the occurrence of TEE, either via immobilisation or the daily use of steroids. A high body surface area (or weight) was identified as a risk factor of TEE in our study. This may be due to a direct effect since obesity is a well-known risk factor of venous TEE (Rosendaal, 1999). Alternatively, it may be due to an indirect factor related to chemotherapy since doses of chemotherapy drugs (except for bleomycin) are prescribed according to body surface area. Interestingly, hypercholesterolaemia has been suggested to be found more often in GCT survivors (Gietema et al, 1992; Raghavan et al, 1992; Meinardi et $a l, 2000)$ and this may be a potential explanation for arterial TEE during chemotherapy for GCT. In contrast, a recent study did not find any correlation between cisplatin administration and lipid profile in GCT survivors (Fenton et al, 2002).

Apart from the potential involvement of treatment-related factors, there is some evidence to support a direct contribution of GCT to the occurrence of TEE. For example, Weijl et al (2000) reported that a number of GCT patients experienced a TEE even though they had not received anticancer treatment. Indeed, we have made similar observations. Moreover, human teratocarcinoma cell lines release plasma membrane vesicles with procoagulant properties (Dvorak et al, 1983). Serum LDH is linked with tumour bulk and prognosis in advanced GCT (Fossa et al, 1997; IGCCCG, 1997) and we show in this study that this factor also predicts the risk of TEE. These findings indirectly support the role of GCT in the occurrence of TEE. Whether the secretion of LDH by GCT cells has a direct effect or is associated with the production of procoagulant factors is unknown.

In our opinion, the high incidence of TEE in GCT patients with either a high body surface area, a high serum LDH, or both, and who receive cisplatin-based chemotherapy is sufficient justification to prospectively evaluate the potential impact of thromboprophylaxis in these patients. However, this strategy needs to be cautiously balanced with the potential risk of thrombocytopenia (although usually mild) related to chemotherapy in patients with GCT. Recently, large studies have demonstrated that subcutaneous low-molecular-weight heparin can be safely used and reduces the risk of TEE in patients with acute medical illnesses (Samama et al, 1999). Moreover, recent randomised trials have suggested that lowmolecular-weight heparin may be safer than vitamin $\mathrm{K}$ antagonists and that they may also be better in reducing the risk of TEE recurrence in cancer patients (Meyer et al, 2002; Lee et al, 2003, 2005)

\section{REFERENCES}

Airey CL, Dodwell DJ, Joffe JK, Jones WG (1995) Etoposide-related myocardial infarction. Clin Oncol (R Coll Radiol) 7: 135

Blokh I, Oiseth SJ, Fuks J, Jain D, Eapen S, Koulova L, Alexandrescu D, Li YY, Dutcher J, Wiernick PH (2003) Metastatic choriocarcinoma in a middle-aged man presenting as a right thigh mass with venous thrombosis: a case report. Med Oncol 20: 189-194

Bosl GJ, Motzer RJ (1997) Testicular germ-cell cancer. N Engl J Med 337: $242-253$

Cantwell BM, Mannix KA, Roberts JT, Ghani SE, Harris AL (1988) Thromboembolic events during combination chemotherapy for germ cell-malignancy. Lancet 2: 1086-1087

Cox DR (1972) Regression models and life-tables. J R Stat Soc 34: 187-220

Culine S, Kerbrat P, Bouzy J, Theodore C, Biron P, Chevreau C, Geoffrois L, Bui B, Kramar A, Droz JP (2003) The optimal chemotherapy regimen for good-risk metastatic non-seminous germ cell tumors (NSGCT) is 3 cycles

of bleomycin, etoposide and cisplatin: mature results of a randomized trial. Proc Am Soc Clin Oncol 22: 382 (Abstr 1536)

Culine S, Kramar A, Biron P, Droz JP (1996) Chemotherapy in adult germ cell tumors. Crit Rev Oncol Hematol 22: 229-263

Doehn C, Buttner H, Fornara P, Jocham D (2000) Fatal basilar artery thrombosis after chemotherapy for testicular cancer. Urol Int 65: $43-45$

Doll DC, List AF, Greco FA, Hainsworth JD, Hande KR, Johnson DH (1986) Acute vascular ischemic events after cisplatin-based combination chemotheray for germ cell tumors of the testis. Ann Intern Med 105: $48-51$

Dvorak HF, Van DeWater L, Bitzer AM, Dvorak AM, Anderson D, Harvey VS, Bach R, Davis GL, DeWolf W, Carvalho AC (1983) Procoagulant activity associated with plasma membrane vesicles shed by cultured tumor cells. Cancer Res 43: 4434-4442 
Fenton DW, Verma S, Venner P, Sawhney R, Mackey JR (2002) The lack of long-term effect of cisplatin based combination chemotherapy on serum cholesterol for treatment of testicular cancer. J Urol 168: 1971 - 1974

Fizazi K, Chen I, Logothetis CJ (2002a) Germ-cell tumor survivors: the price for cure. Ann Oncol 13: 187-189

Fizazi K, Do KA, Wang X, Finn L, Logothetis CJ, Amato RJ (2002b) A 20\% dose reduction of the original CISCA/VB regimen allows better tolerance and similar survival rate in disseminated testicular non-seminomatous germ-cell tumors: final results of a phase III randomized trial. Ann Oncol 13: $125-134$

Fizazi K, Dohollou N, Missenard G, Merad M, Levy C, Terrier P, Vanel D, Llombart A, Spielmann M, Le Cesne A (1997) Rapidly recycled doxorubicin, ifosfamide and cisplatin + G-CSF (API-AI regimen) associated with surgery and radiotherapy: a highly effective therapy in adults with the Ewing's sarcoma family of tumors. Proc Am Soc Clin Oncol 16: 499a

Fossa SD, Oliver RTD, Stenning SP, Horwich A, Wilkinson P, Read G, Mead GM, Roberts JT, Rustin G, Cullen MH, Kaye SB, Harland SJ, Cook P (1997) Prognostic factors for patients with advanced seminoma treated with platinum-based chemotherapy. Eur J Cancer 33: 1380-1387

Gerl A (1994) Vascular toxicity associated with chemotherapy for testicular cancer. Anticancer Drugs 5: 607-614

Gerl A, Schierl R (2000) Urinary excretion of platinum in chemotherapytreated long-term survivors of testicular cancer. Acta Oncol 39: 519-522

Gietema JA, Sleijfer DT, Willemse PH, Schraffordt Koops H, van Ittersum E, Verschuren WM, Kromhout D, Sluiter WJ, Mulder NH, de Vries EG (1992) Long-term follow-up of cardiovascular risk factors in patients given chemotherapy for disseminated nonseminomatous testicular cancer. Ann Intern Med 116: 709

Hassan B, Tung K, Weeks R, Mead GM (1999) The management of inferior vena cava obstruction complicating metastatic germ cell tumors. Cancer 85: $912-918$

Huddart RA, Norman A, Shahidi M, Horwich A, Coward D, Nicholls J, Dearnaley DP (2003) Cardiovascular disease as a long-term complication of treatment for testicular cancer. J Clin Oncol 21: 1513-1523

Icli F, Karaoguz H, Dincol D, Demirkazik A, Gunel N, Karaoguz R, Uner A (1993) Severe vascular toxicity associated with cisplatin-based chemotherapy. Cancer 72: $587-593$

International Germ Cell Consensus Classification (1997) A prognostic factor-based staging system for metastatic germ cell cancers. J Clin Oncol 15: $594-603$

Koga F, Yamada T, Ishimaru H, Sadaoka SI, Mizuo T (2001) Deep vein thrombosis during chemotherapy in a patient with advanced testicular cancer: successful percutaneous thrombectomy under temporary placement of retrievable inferior vena cava filter. Int J Urol 8: 90-93

Lee AY, Levine MN, Baker RI, Bowden C, Kakkar AK, Prins M, Rickles FR, Julian JA, Haley S, Kovacs MJ, Gent M (2003) Randomized comparison of low-molecular-weight heparin vs Oral anticoagulant therapy for the prevention of recurrent venous thromboembolism in patients with cancer (CLOT) investigators. Low-molecular-weight heparin vs a coumarin for the prevention of recurrent venous thromboembolism in patients with cancer. $N$ Engl J Med 349: 146-153

Lee AY, Rickles FR, Julian JA, Gent M, Baker RI, Bowden C, Kakkar AK Prins M, Levine MN (2005) Randomized comparison of low molecular weight heparin and coumarin derivatives on the survival of patients with cancer and venous thromboembolism. J Clin Oncol 23: 2123-2129

Leslie JA, Stegemann L, Miller AR, Thompson IM (2003) Metastatic seminoma presenting with pulmonary embolus, inferior vena caval thrombosis, and gastrointestinal bleeding. Urology 62: 144

Levine MN, Rickles F, Kakkar AK (2002) Thrombosis in cancer patients. ASCO Educ Book Spring 57-60

Meinardi MT, Gietema JA, van der Graaf WTA, van Veldhuisen DJ, Runne MA, Sluiter WJ, de Vries EG, Willemse PB, Mulder NH, van den Berg MP, Koops HS, Sleijfer DT (2000) Cardiovascular morbidity in long-term survivors of metastatic testicular cancer. J Clin Oncol 18: 1725-1732

Meyer G, Marjanovic Z, Valcke J, Lorcerie B, Gruel Y, Solal-Celigny P, Le Maignan C, Extra JM, Cottu P, Farge D (2002) Comparison of lowmolecular-weight heparin and warfarin for the secondary prevention of venous thromboembolism in patients with cancer: a randomized controlled study. Arch Intern Med 162: 1729-1735

Nichols CR, Roth BJ, Williams SD, Gill I, Muggia FM, Stablein DM, Weiss RB, Einhorn LH (1992) No evidence of acute cardiovascular complications of chemotherapy for testicular cancer: an analysis of the Testicular Cancer Intergroup Study. J Clin Oncol 10: 760-765

Peto R, Pike MC, Armitage P, Breslow NE, Cox DR, Howard SV, Mantel N, Mc Pherson K, Peto J, Smith PG (1977) Design and analysis of randomized clinical trials requiring prolonged observation of each patient. II. Analysis and examples. Br J Cancer 35: 1-39

Raghavan D, Cox K, Childs A, Grygiel J, Sullivan G (1992) Hypercholesterolemia after chemotherapy for testis cancer. I Clin Oncol 10: 1386-1389

Rosendaal FR (1999) Venous thrombosis: a multicausal disease. Lancet 353: $1167-1173$

Samama MM, Cohen AT, Darmon JY, Desjardins L, Eldor A, Janbon C, Leizorovicz A, Nguyen H, Olsson CG, Turpie AG, Weisslinger N (1999) A comparison of enoxaparin with placebo for the prevention of venous thromboembolism in acutely ill medical patients. Prophylaxis in Medical Patients with Enoxaparin Study Group. $N$ Engl J Med 341: $793-800$

Schilsky RL, Barlock A, Ozols RF (1982) Persistent hypomagnesemia following cisplatin chemotherapy for testicular cancer. Cancer Treat Rep 66: $1767-1769$

Schwarzer S, Eber B, Greinix H, Lind P (1991) Non-Q-wave myocardial infarction associated with bleomycin and etoposide chemotherapy. Eur Heart J 12: $748-750$

Trousseau A (1865) Phlegmasia alba dolens. In Clinique Medicale de l'Hotel-Dieu de Paris (vol 3) pp 654-712. Paris, France: JB Balliere et Fils

Weijl NI, Rutten MF, Zwinderman AH, Keizer HJ, Nooy MA, Rosendaal FR, Cleton FJ, Osanto S (2000) Thromboembolic events during chemotherapy for germ cell cancer: a cohort study and review of the literature. J Clin Oncol 18: 2169-2178 